\title{
The Effectiveness Of Mathematical Learning Tools Based On Thinking Aloud Pair Problem Solving (Tapps) Towards The Problem Solving Ability Of Grade X High School Students
}

\author{
$1^{\text {st }}$ Sunarti Yola Sri Widuri \\ Mathematics Departement \\ State University of Padang \\ Padang, Indonesia \\ yolawiduri@yahoo.com
}

\author{
$2^{\text {nd }}$ Edwin Musdi \\ Mathematics Departement \\ State University of Padang \\ Padang, Indonesia \\ Win_musdi@yahoo.co.id
}

\begin{abstract}
The purpose of this research is to know the effectiveness of mathematical learning tools based on Thinking Aloud Pair Problem Solving (TAPPS) towards the problem solving ability of grade $X$ high school students. TAPPS's technique is applied by using student's worksheet. The trial is done on 32 grade $X$ students at SMAN 1 Batang Anai. The testing of effectiveness is refers to provision in quasi experiment. The design model is Posttest-Only Control. The conclusion of this study is the student's problem solving ability that use mathematical learning devices based on Thinking Aloud Pair Problem Solving (TAPPS) are higher than the student's problem solving ability without TAPPS of Trigonometry lesson.
\end{abstract}

Keywords-Effectiveness, Learning device, Problem solving ability Introduction, Thinking Aloud Pair Problem Solving

\section{INTRODUCTION}

The purpose of mathematics learning according to the National Council of Teachers Of Mathematics (NCTM) that the standard mathematical skills that must be have by students in learning mathematics is problem solving, reasoning and proof, communication, connections, and representation [1].

In achieving the objectives of mathematics learning above, teachers should do the planning, implementation and assessment during learning activities. Teachers are required to carry out active, creative and innovative learning. To develop teachers' ability in the teaching process, the government has implemented innovations in the teaching system such as: carrying out training for teachers in the hope of improving the quality of teachers, supplementing educational facilities and supplementing educational infrastructure and improving the curriculum by applying the curriculum 2013. However, in reality the results of this innovations are not optimal. It can be seen from international students' achievement.

The result of international study of Trends in International Mathematics and Science Study (TIMSS) in 2015 , Indonesia ranked 45 out of 50 countries. In the survey one of the cognitive aspects assessed is the ability of applications where it contains the ability of learners to solve problems [2]. Meanwhile, the results of tests for the International Student Assessment Program (PISA) in 2015, Indonesia ranked 63 out of 71 participating countries. In the survey one aspect that is assessed is the ability to solve mathematical problems [3]. The results of TIMSS and PISA provide information that the achievement of Indonesian children in the field of mathematics is still not optimal. One of the causes is the ability of problem solving students is still low. Therefore it takes learning that can encourage and inspire students to think critically, analytically, systematically, and logically in understanding problems and solving problems.

Based on observations at SMAN 1 Batang Anai, SMAN 1 VII Koto Sungai Sarik, and MAN 1 Lubuk Alung in August 2017, obtained information that the learning has been using curriculum 2013. Learning using scientific approach. Teaching materials used by teachers are Mathematics Books from Kemendikbud. Students are not equipped with Student Worksheet.

During the learning of mathematics, students tend to be passive, just listen and record the concept of the teacher submitted with the application of a question. Only a few students who ask teachers and they`re the same students. In accordance with the opinion Rajagukguk (2011) students tend to memorize mathematical concepts so that their ability in solving problems is very less [4].

Then, the teacher has tried to apply the discussion learning, but in the group discussion not all students participate, smart students want to take over all the tasks of the group. Other students only expect answers that have been done by their friends. Students tend not to try to complete the training given by the teacher because they are used to copying answers from friends of a group. Furthermore, in discussing the results of the discussion in front of the class, it is seen that only active students smart. It can be said that the liveliness and the sense of responsibility of students in learning is still lacking.

Then, when students work on individual practice questions, with different problems with sample questions, students have difficulty to do that. If they are stumble while doing the excercises, they do not want to continue the exercise so 
that during the mathematics learning, the students prefer to do other tasks and want the learning process quickly completed. This such of activities ultimately lead students become saturated and mistrust of mathematics. All of these things come from students who can not continue their individual excersice. This can happen because of the low problem solving ability of students.

Low problem solving ability of students is also shown by the results of mathematics tests given to students of class X SMAN 1 Batang Anai, SMAN 1 VII Koto Sungai Sarik, and MAN 1 Lubuk Alung in August 2017. Students have difficulty solving problems on the subject system linear equations of three variables. Of the approximately 32 students in the classroom only 3 to 5 people are able to find ideas to solve the problem.

The students was given the following problem, "Once Pak Raden got an order to make 3 carved statues from a tourist from Australia with a time limit of making given for 3 days. Pak Raden and Unyil can complete the above three types of engraving within 3 days. If Pak Raden works with Bolang, they can complete the order within 2 days. If Unyil works with Bolang, they need 4 days to complete the engraving order because Unyil and Bolang work after school. Can the order of engraving be completed / fulfilled, if Pak Raden assisted his two children with the deadline given?".

After being tested in several classes, the students' answers to this issue vary. Most of the students answered wrongly, as many as $86.36 \%$ of the students mistakenly solve the problem. Most students are wrong in analyzing the problem so the end result is also wrong. Thus it can be said that the problem solving ability of the students is low.

The results of interviews with teachers of mathematics class X SMAN 1 Batang Anai, SMAN 1 VII Koto Sungai Sarik, and MAN 1 Lubuk Alung obtained information that the ability of students is varies, teachers have tried to implement learning discussion but not going well and learning is not supported by student's worksheet (LKPD). If the teacher gives an example of type $\mathrm{A}$ and then the teacher gives the exercise of type $\mathrm{B}$, after examined only a small percentage of students who can complete correctly. Students mostly misunderstand the meaning of the problem that causes the end result is also wrong.

Information is also obtained from interviews conducted with students stating that learners have difficulties in understanding examples of problems contained in the handbook. Then the students also express that mathematics is a difficult lesson if the given problem is different from the example of the questions given by the teacher and more difficult when the question is in story form. It affects the low mathematics learning outcomes of students on the assessment of the end of the first semester of the academic year 2017/2018. The low learning outcome of mathematics of students is caused by the lack of mathematical problem solving ability of students. On the matter of final evaluation of the semester also contains a story that most students cannot do it.

To overcome the problems that have been described above, it is necessary learning techniques that can help students' active, responsible and can communicate the idea with the group to solve the problem that is Thinking Aloud Pair Problem Solving (TAPPS). By using TAPPS the process of discussion become directional and clear about the tasks that must be done each students. In accordance with Wah's opinion (1998) TAPPS is a useful strategy for developing students 'awareness to engage in problemsolving processes and can help develop students confidence in solving problems [5]. Then according to Kyungmoon Jeon (2005) TAPPS was developed by Arthur Whimbey to help students monitor and understand their own thought processes [6]. The TAPPS strategy encourages students to interact verbally with each other to solve problems.

The purpose of this research is to know the effectiveness of TAPPS-oriented mathematics learning device. The effectiveness of device learning in term of the ability problem solving students. Benefit the result of this research been the availability of example device learning mathematics to technique TAPPS, can develop skill problem solving mathematics studends. The TAPPS technique will be applied in the classroom with teacher guides based on the RPP and the guidance provided in LKPD.

\section{METHODS}

A device of learning that have been developed are tested at SMAN 1 Batang Anai. The class $\mathrm{X}$ population is 161 students ( 5 class). While the sample of the study were 32 students X-IPS class 3 as the experimental class and 31 students class X-IPS 2 as a control class selected by random sampling. The experiment class is a class that uses TAPPSoriented learning device, while the control class is a class that does not use TAPPS-oriented learning device. The research design used is Posttest-Only Control Design.

The data collected is the acquisition of the value taken through the final test of problem-solving skills. The data analysis used is Independent Sample T-Test (SPSS) to seen the effect of TAPPS learning device on problem solving ability. If the value of sig. ( 2 tailed) $<0.05$ then it can be interpreted the problem solving ability of learners using TAPPS-oriented learning device higher than the problem solving ability of learners who do not use TAPPS-oriented learning device. Prior to data analysis, normality and homogeneity tests were conducted first.

\section{RESULT}

The result of the application on the subject matter of Graph Trigonometric Function, average results of the final test in problem solving ability for learners using TAPPSoriented mathematics learning device is 74,31 while the mean value of final test of problem solving ability for learners who do not use TAPPS-oriented learning device is 68.03. The indicates value class experimentation with greater higher than value class control.

The results of the normality about the test scores the end of the ability solving problems by using SPSS can be seen in table I below.

Table I. The Result of Normality Test

\begin{tabular}{|c|c|c|}
\hline No & Class & Sig. \\
\hline 1 & Experiment & 0,063 \\
\hline 2 & Control & 0,200 \\
\hline
\end{tabular}

Based on table above it is seen that the value of Sig. Experimental class and control class> 0.05 , then the final 
test score value of problem solving ability of learners normally distributed.

Homogeneity test results about the acquisition of final test of problem solving ability by using SPSS can be seen in table II below.

Table II. The Result of Homogenity Test

\begin{tabular}{|c|c|}
\hline & Sig. \\
\hline Based on Mean & 0,392 \\
\hline
\end{tabular}

Based on the above table shows that the value of Sig. Based on Mean> 0.05, there is no variant difference in each class, meaning that the variant values in the experimental and control classes are homogeneous.

After the data is normally distributed and homogeneous, then further data analysis is calculated that is Independent Sample T-Test. The Independent Sample TTest test result on the final test of problem solving ability using SPSS can be seen in table III below.

Table III. The Result Test Independent Sample T-Test

\begin{tabular}{|c|c|}
\hline & Sig.(2-tailed) \\
\hline $\begin{array}{c}\text { Equal Variances } \\
\text { Assumed }\end{array}$ & 0,023 \\
\hline
\end{tabular}

Based on the above table shows that the value of Sig (2 tailed) $<0,05$, then there is a significant difference between students problem solving ability of experimental class with the students problem solving ability of control class. Thus, the TAPPS-oriented learning tool is effective to improve students' problem solving abilities. This is in line with the results of research conducted by Yenti the application of TAPPS techniques affect the ability of problem solving mathematical learners [7] and research Aminah application of thinking technique aloud pair problem solving (TAPPS) can improve problem solving ability mathematically learners [8].

The steps of learning TAPPS are: (1) students are divided into pairs and explained the roles of problem solvers and listeners. The problem solver is tasked with reading out the problem and explaining the solution orally. Listeners are tasked with asking questions and giving suggestions, (2) Students solve several problems and change roles in each new problem, (3) The activity is stopped if all the problems are solved by the students [9]. These steps show studentcentered learning.

In this research, the steps of TAPPS learning techniques applied in the classroom are modified in such a way without reducing and destroying the content of the original TAPPS learning technique steps. Such as: (1) the formation of a group of more are to be given priority on the capacity of the academic ability of learners. (2) the size of one group is not only divided into two students (pair), but in each group consists of four learners (two pairs). If in one group there are only two students, then there will be no interaction between learners.

TAPPS learning steps are in line with Piaget and Vygotsky's theories, learners interact and collaborate, both between teachers with learners, and learners who are one with other learners that is problem solver and listener so as to develop the ability to think in solving problems.

\section{IV.CONCLUSIONS AND RECOMMENDATIONS}

There is a significant difference between students problem solving ability of experimental class with the students problem solving ability of control class. So it can be concluded that the TAPPS-oriented learning tool is effective to improve students' problem solving abilities on Trigonometry materials. Therefore, it is advisable for TAPPS-oriented mathematics learning device to be used by teachers in schools.

\section{REFERENCES}

[1] National Council of Teachers of Mathematics, Principles and Standarts for School mathematics, Reston, VA: NCTM, 2000.

[2] Mullis, Ina V.S, et al, TIMSS 2015 International Result in Mathematics (Trends in International Mathematics and Science Study at The Fourth and Eight Grades), Chesnut Hill, MA: TIMSS \& PIRLS International Study Center, Boston College, 2015.

[3] OECD, PISA 2015 Assessment and Analytical Framework: Science, Reading, Mathematic, Financial Literacy And Collaborative Problem Solving, OECD publishing, Paris, 2015.

[4] Rajagukguk. W, "Upaya Meningkatkan Kemampuan Pemecahan Masalah Matematika Peserta didik dengan Penerapan Teori Belajar Bruner pada Pokok Bahasan Trigonometri di Kelas X SMA Negeri 1 Kualuh Hulu Aek Kanopan T.A. 2009/2010”, Jurnal VISI, 2011.

[5] Wah. L. L. K, "Thinking Aloud about pair problem solving in chemistry", Institude of Education (Singapore).Journal Teaching \& Learning vol. 18, 1998.

[6] Kyungmoon. J, "The Effects of Thinking Aloud Pair Problem Solving on High School Students' Chemistry Problem-Solving Performance and Verbal Interactions", Journal of Chemical Education, vol. 82, pp. 1558-1564, 2005.

[7] Yenti, S Wirma, "Pengaruh Penerapan Teknik TAPPS terhadap Kemampuan Pemecahan Masalah Matematis Siswa Kelas VII MTsN Model Padang Tahun Pelajaran 2013/2014”, Padang : Universitas Negeri Padang, 2014.

[8] Aminah, L. Lusiyana, "Penerapan Teknik Pembelajaran Thinking Aloud Pair Problem Solving (TAPPS) untuk Meningkatkan Kemampuan Pemecahan Masalah Matematis pada Pokok Bahasan Kubus dan Balok di Kelas VIII-5 SMP Negeri 27 Jakarta”, Jakarta: Universitas Negeri Jakarta, 2016.

[9] Barkley, Elizabert. E., Cross, K.Patricia \& Major, Clair Howell, "Collaborative Learning Techniques: Teknik-teknik Pembelajaran Kolaboratif", Penerjemah: Narulita Yusron. Bandung: Nusa Media, 2012 . 